\title{
POMACY - BUŁGARSCY POTURCZEŃCY (NA PRZYKŁADZIE WSI SELCZA W ZACHODNICH RODOPACH)
}

\author{
MARIOLA WALCZAK-MIKOŁAJCZAKOWA
}

\begin{abstract}
Mariola Walczak-Mikołajczakowa, Pomacy - bułgarscy poturczeńcy (na przykładzie wsi Selcza w zachodnich Rodopach) (Pomaks - Turkified Bulgarians (on the example of Selcha village in the Western part of the Rhodope mountains)).

The Selcha village, situated at the Smolian District, inhabited by Pomaks, a specific ethnos, came into being after accepting Islam, most likely at the turn of the 16th and the 18th century. The Author attempts to recreate a complicated history of this village.
\end{abstract}

KEYWORDS: Pomaks, turkiefied Bulgarians history, culture, traditions

Balcanica Posnaniensia. Acta et studia, XXI, Poznań 2014, Wydawnictwo Instytutu Historii UAM, pp. 177-184, ISBN 978-83-63047-59-7, ISSN 0239-4278. Polish text with a summary in English.

Mariola Walczak-Mikołajczakowa, Uniwersytet im. Adama Mickiewicza, Instytut Filologii Słowiańskiej, ul. Fredry 10,61-701 Poznań, mawal@amu.edu.pl.

Selcza jest wsią, czy może raczej miejscem osadnictwa o wielowiekowej tradycji sięgającej czasów trackich, o czym świadczą artefakty odkrywane tam przez archeologów, a także współczesnych ,poszukiwaczy skarbów”. Na temat jej założenia krążą wyłącznie mity i legendy, zebrane i opublikowane przed kilkoma laty przez miejscowego historyka-amatora ${ }^{1}$. Pierwsze dane pisemne na temat istnienia wsi pochodzą z tureckich rejestrów podatkowych z roku $1489^{2}$. Podobnie w kolejnych wiekach o historii Selczy można dowiedzieć się tylko tyle, ile zapisano w tego rodzaju rejestrach (wieś figuruje w nich także pod nazwą Selcze). W 1870 roku Stefan Zachariew, zatrudniony jako osmański urzędnik finansowy opublikował Geograficzno-historycznostatystyczny opis Tatar-Pazardżijskiej Kaazy³, w którym odnotował, że Selcza leży 3,5 godziny drogi na północ od Dewin i 13 godzin od na południe od Tatar-Pazardżik (dziś miasto Pazardżik, ok. 30 km na północ od Płowdiwu), że jest w niej 30 domów,

\footnotetext{
1 Я. Шуров, Миналото на село Селча, Смолян 2008, s. 17-41.

2 Państwowe Archiwum Republiki Turcji w Stambule, Istanbul - BOA, TD 26.

${ }^{3}$ Fototypiczne wydanie współczesne: С. Зазариев, Географско-историко-статистическо описание на Татар Пазарждишка кааза, Пазарджик 1973.
} 
jedna dżamija (meczet) i mieszka tam około stu Pomaków trudniących się rolnictwem, smolarstwem oraz dziegciarstwem.

Dość szczególne położenie wsi spowodowało że po podpisaniu traktatu zjednoczeniowego Bułgarii w 1886 roku Selcza wraz z 20 innymi wsiami pozostała w granicach imperium osmańskiego w obrębie tzw. Autonomicznej Republiki Tymrasz, (zwanej „republiką pomacką”, która jednoczyła tzw. „niepokorne wsie”), powołanej po wojnie rosyjsko-tureckiej w 1878 roku i nie uznanej nigdy przez żadne traktaty międzynarodowe ${ }^{4}$. Oddalenie od głównych traktów aż do lat dwudziestych XX wieku czyniło wieś enklawą odizolowaną od reszty świata w granicach imperium osmańskiego ${ }^{5}$. Wojna z Turcją w roku 1912 spowodowała wyludnienie wsi, jej mieszkańcy, nękani głodem, próbowali znaleźć schronienie gdzie indziej, co jednak się nie powiodło i rok później zmuszeni byli powrócić do porzuconych uprzednio siedzib ${ }^{6}$. Włączenie Selczy i okolic tej wsi do Bułgarii nastapiło po podpisaniu tzw. bukaresztańskiej umowy pokojowej 10 sierpnia $1913 \mathrm{r}$.

$\mathrm{Na}$ współczesnej mapie Bułgarii Selczy należy szukać w okręgu Smolian, około 14 kilometrów od drogi prowadzącej z Dewin do Kriczim, na wysokości ponad 1100 metrów nad poziomem morza. Nieopodal przepływają rzeki Wycza i Gaszna. Budowa zapory wodnej na tej pierwszej zapewniała w ostatnich latach zatrudnienie większości mieszkańcom wsi. Jej ukończenie w 2012 roku spowodowało wzrost bezrobocia i kolejny odpływ ludności do najbliżej położonych miast, gdzie mogli znaleźć pracę. Ze względu na zmiany gospodarcze, jakie dokonały się w ostatnich 25 latach (likwidacja państwowych gospodarstw rolnych, uwolnienie rynku itp.), ta duża, w połowie XX wieku licząca ponad $1900^{7}$ mieszkańców wieś stopniowo się wyludnia - w ostatnich wyborach samorządowych w 2013 r. uprawnionych do głosowania było $639 \mathrm{osób}^{8}$. Zmienia się też struktura wiekowa ludności - niewiele jest tu obecnie osób poniżej 60 roku życia, ogromna, wybudowana w latach 70. XX wieku szkoła jest obecnie nieczynna, a kilkoro zaledwie uczniów dojeżdża do szkół w innych pobliskich miejscowościach. Wraz z odpływem młodego pokolenia w niepamięć odchodzą także dawne tradycje i obyczaje.

Wydawać by się mogło, że przytoczony wyżej opis wsi dotkniętej kryzysem gospodarczym może dotyczyć dowolnej bułgarskiej miejscowości poddanej bezlitosnym prawom wolnego rynku po zmianach ustrojowych w 1990 r., w wypadku Selczy pro-

\footnotetext{
${ }^{4}$ А. Вълчев, Тъмрам, София, 1973.

5 Хр. П. Константинов, Непокорните села в Родопските планини, кн. I-II, София 1886. Dane dotyczące liczby mieszkańców tzw. odrińskiego wilajetu (Okręgu Odrin) po 1913 r., czyli po wojnie bałkańskiej, która zmieniała granice państw znajdujemy w opracowaniu Lubomira Mileticza Разорението на тракийските българи през 1913 година, София 1918. Według tego autora opisywane przez niego terytorium zamieszkiwało w 1913 r. 95,5 tys. Pomaków.

6 Я. Шуров, оp. cit. s. 102.

${ }^{7}$ Brak dokładnych danych statystycznych na temat liczby mieszkańców w poszczególnych latach. Fragmentaryczne dane można znaleźć w monografii napisanej przez mieszkańca Selczy, Jasena Szurowa, amatora-historyka i etnografa: Я. Шуров, Миналото на село Снлча, Смолян 2008.

${ }^{8}$ www. blitz. bg (dostęp 11.02.2014).
} 
cesy stopniowej degradacji mają jednak o wiele głębsze podłoże i trwają niezmiennie od połowy lat siedemdziesiątych, kiedy rząd Todora Żiwkowa podjął kolejną już w historii Bułgarii próbę przymusowej bułgaryzacji mieszkańców Rodopów ${ }^{9}$. Selcza jest bowiem wsią zamieszkałą przez Pomaków, specyficzny etnos, który wytworzył się tutaj po przyjęciu islamu, najprawdopodobniej na przełomie XVI i XVII wieku. Pomakami określani są bułagrskojęzyczni muzułmanie, którzy przyjęli islam w czasach, kiedy ziemie te wchodziły w skład imperium osmańskiego. Dane o liczebności Pomaków zmieniały się wraz z przesuwaniem południowo-zachodnich granic państwa bułgarskiego i na przestrzeni stu lat (od wyzwolenia Bułgarii w 1878 r. do czasów współczesnych) wahały się od 20 tys. do ponad 200 tys. osób. Precyzyjnych danych nie przyniósł także najnowszy spis ludności z 2011 r., nie uwzględniono w nim bowiem emigracji.

Społeczność pomacka bywa postrzegana bardzo niejednoznacznie. W bułgarskiej mitologii narodowej ważną rolę odgrywa obraz Pomaków jako etnicznych Bułgarów, co determinuje niejednoznaczny często emocjonalny stosunek do tej ludności, która z jednej strony uznawana jest za apostatów, z drugiej zaś za „swoich” muzułmanów i ,najczystszych”, bo wiernych pradawnym tradycjom narodu Bułgarów ${ }^{10}$.

Z tych właśnie względów, a może przede wszystkim z powodu postępującej ateizacji, Pomacy zamieszkujący Selczę stanowią grupę wyjątkową, niepoddającą się łatwemu definiowaniu - tak jak niejasne jest ich pochodzenie, jak owiane wieloma legendami są okoliczności ich przejścia na islam, tak też ich obecna autoidentyfikacja i postrzeganie przez świat zewnętrzny są zróżnicowane. Od dłuższego czasu toczy się na ten temat ożywiona dyskusja na forach internetowych (Selcza przed kilkoma laty być może ze względu na wytyczenie nowych tras turystycznych, być może ze względu na związany z budową zapory napływ obcokrajowców i turystów do wsi) stała się ulubionym obiektem uwagi bułgarskich internautów (szczególnie tych, którzy w jakiś sposób są z Selczą związani). Jej rezultaty wyjątkowo trafnie podsumowuje jeden z wpisów, jednocześnie wprowadzając niewygodny dla większości mieszkańców wsi wątek niegdysiejszego zamieszkiwania tam Turków - mieszkańcy Selczy nie znają bowiem języka tureckiego, podkreślają swoją bułgarską ,starożytność” i dzisiaj już tylko jedna z kobiet potrafi zaśpiewać ludową piosenką po turecku, przy czym jest to jedynie imitowanie języka tureckiego, gdyż staruszka ta nie rozumie słów, które śpiewa, a jedynie naśladuje to, co śpiewała jej babcia:

Чела съм и монографията за селото написана от Ясен Шуров, но и там не разбрах какви са селчанци в крайна сметка - траки, кумани, славяни, българи, или помаци. За това искам да чуя повече мнения като на тази, все пак селчанка, на която успях да открия спомените. Нали за това е форум всеки да поднесе нещо по-различно и по-близко до истината. А за това, че в Селча

${ }^{9}$ Pierwsza próba masowej chrystianizacji miała miejsce po zwycięstwach w pierwszej wojnie bałkańskiej 1912-1913; na ten temat zob. hasło Pomacy w: Leksykon tradycji butgarskiej, red. G. Szwat-Gyłybowa, Warszawa 2001, s. 226-230.

${ }^{10}$ Leksykon tradycji... op. cit. s. 226. 
доста от родовете са били турски, но сега са български са благодарение на възродителните процеси започнали още 1912 година в Родопите ${ }^{11}$.

W latach 2007-2010, zbierając materiały do książki, wysłuchałam na temat tożsamości i autoidentyfikacji selczan wielu relacji mieszkańców wsi, publikując kilka z nich, m.in.:

\begin{abstract}
A o tym, że Pomacy, to najstarożytniejsi ze starożytnych Bułgarów, to już dawno pisali. ${ }^{12}$ A kto to Pomacy? Powiedz mi? Gorsi Bułgarzy? [...] A ja ci powiem, że my nie gorsi tylko najprawdziwsi, bo ta wieś ma już parę tysięcy lat. Ja się na tym nie znam, ale wiem, że tutaj wieś od zawsze była, tyle setek lat była, najpierw tracka, potem bułgarska. I taka już została. Bo co z tego, że my muzułmanie? Czy my po bułgarsku nie mówimy? Szurow książkę teraz o naszej wsi pisze, dokumenty zbiera, do archiwów jeździ. Podobno nawet w Stambule był. Jak z nim porozmawiasz to się dowiesz, że Pomacy to Bułgarzy - i nie gorsi, tylko tacy, co wiarę zmienili. Ale to nie ja zmieniałam. Nawet nie moja babcia, to jeszcze dawniej było. Teraz to moja tradycja, moje obyczaje i ja się ich wyrzekać nie będę, niech mnie za gorszą mają. Zresztą co z tego, że wiarę zmienili - języka nie zmienili i wieś nawet w tureckich czasach nazywała się tak, jak teraz.
\end{abstract}

Być może ta niewykształcona kobieta powtarzała jedynie zasłyszaną gdzieś opowieść,jakby wprost zaczerpniętąz Notateko Bułgarii i Bułgarach Lubena Karawełowa, jednego z bardziej poczytnych pisarzy II połowy XIX wieku ${ }^{13}$. Karawełow bowiem $\mathrm{w}$ notatkach publikowanych na łamach rosyjskiej i bułgarskiej prasy (a potem, w 1940 roku zebranych w jeden tom) propagował obraz Pomaków, którzy żyjąc w izolacji, przechowali w nietkniętej postaci największe skarby ojczystego folkloru, języka i tradycji ${ }^{14}$.

Na marginesie należy zauważyć, że wyczerpującego wyjaśnienia nie doczekał się dotąd etnonim Pomacy. W tradycji bułgarskiej popularna jest etymologia wywodząca tę nazwę od imiesłowu помъчен, czyli 'umęczony', co sugeruje przymusowy, niejako męczeński charakter islamizacji, utrwalony w bułgarskiej literaturze i kinematografii ${ }^{15} . \mathrm{Z}$ drugiej strony dystansował się od niego Iwan Wazow, wywodząc etymologię etnonimu od rzeczownika помагачи, co akurat w wypadku Selczy miałoby swoje uzasadnienie, gdyż mieszkają oni na ulubionych terenach łowieckich kilku sułtanów i mogli pomagać $\mathrm{w}$ organizacji polowań

Inny punkt widzenia na temat pochodzenia Pomaków prezentuje tzw. koncepcja turecka, według której Pomacy mają niebułgarski rodowód i wywodzą się od Kumanów, którzy osiedlili się tu w XI wieku i ze Słowianami zetknęli bardzo późno, być może dopiero na początku XX wieku), a ich osobliwy dialekt ma swoje źródło w slawizacji miejscowej tureckiej gwary (nawiasem mówiąc, jeśli chodzi o ję-

11 www.pomak.eu (dostęp 27.04.2014).

12 M. Mikołajczak, Powiedz mi swoje imię, Nowa Ruda 2011, s. 18.

13 Л. Каравелов, Записки за България и за българите, София 1940.

${ }^{14}$ Leksykon tradycji..., s. 226.

15 Por. А. Дончев, Време разделно, София 1964. Powieść ta, zekranizowana w 1987 r. przez Ludmiła Stajkowa, służyła jako narzędzie propagandy państwowej. 
zyk mieszkańców Selczy, to brak w nim najbardziej osobliwej cechy dialektów rodopskich, jaką jest łączenie kategorii określoności z kategorią odległości i używanie trzech typów rodzajników ${ }^{16}$ ). Trzecia koncepcja, szczególnie propagowana w latach 90. XX wieku, rozpowszechniła wśród Pomaków przekonanie, że są oni ,achrenami” (ахър мюсюлмани 'ostatni muzułmanie'), czyli duchowymi potomkami wysłanników Mahometa, którzy zawędrowali na Bałkany, by miejscową ludność nauczyć prawowitej wiary ${ }^{17}$. Jeszcze inne koncepcje mówią o rodowodzie tracko-greckim ${ }^{18}$.

Mieszkańcy Selczy skłaniają się ku pierwszej, rozpropagowanej przez Lubena Karwełowa koncepcji, co być może jest spowodowane ich niezbyt gorliwym w ciągu ostatnich co najmniej 40 lat zaangażowaniem w sprawy wiary. Zaawansowana ateizacja wsi sprawiła, bowiem, że nawet w piątki miejscowy meczet odwiedzało w ostatnich latach zaledwie dwóch starców, pozostali mieszkańcy wsi pozostawali obojętni na nawoływania muezina do modlitwy ${ }^{19}$. Jedyną okolicznością gromadzącą Selczan na modlitwie były pogrzeby (tradycyjnie na miejscowym cmentarzu chowani są wszyscy, którzy z Selczy pochodzą). Na marginesie należy zauważyć, że przez ostatnich kilkadziesiąt lat jedynie na nagrobkach odnotowywano prawdziwe, muzułmańskie imię i nazwisko zmarłego, chociaż wiele kamiennych płyt opisanych jest po bułgarsku i zwiera często nie tylko imię nazwisko, ale także, zgodnie z bułgarską tradycja, przydomek zmarłego, pod którym był on znany lokalnej społeczności, np. Сенатора, Водопроводчика itp. Ten ostatni przypadek zasługuje na szczególną uwagę, ponieważ mieszkańcy Selczy wspominając tego człowieka nazywają go używając jego bułgarskiego imienia, a jednocześnie tureckiego odpowiednika bułgarskiej oficjalnej nazwy zawodu водопроводчик utrwalonej na nagrobku - w ich wspomnieniach jest to Сашо Чешмеджия.

Podobnie zreszta, w oficjalnym użyciu do dziś pozostają nadane w latach 70 . i 80. imiona i nazwiska bułgarskie (rzadko chrześcijańskie, dużo częściej mające rodowód w czasach pogańskich (Rosen, Swilen, Jasen, Kitka, Krasimir, Cwetelina itp.) lub o proweniencji literackiej (Albena), podczas gdy w użyciu domowym są imiona pochodzenia tureckiego, które niechętnie wyjawiają obcym (większość prawdziwych imion mieszkańców Selczy poznałam dopiero po kilku latach, kiedy nabrali do mnie większego zaufania ${ }^{20}$ ). Pytani o możliwość wyboru nowego imienia mieszkańcy Selczy mówili o specjalnych spisach, z których dobierali takie imię, które wyda-

$16 \mathrm{Na}$ temat dialektów rodopskich zob. С. Стойков, Българска диалектология, изд. 4, София 2002, c. 127-139.

17 Leksykon tradycji..., s. 227.

18 А. Желязкова, Мюсюлманските общности на Балканите и в България. Исторически ескизи, серия «Съдбата на Мюсюлманските общности на Балканите и в България», т. 1, ред, А. Желязкова, София 1997.

${ }^{19}$ Być może uległo to zmianie, gdyż w 2012 r. po śmierci ich dotychczasowego duchowego przywódcy, miejscowym hodża został młody, wykształcony w Arabii Saudyjskiej mężczyzna, dużo bardziej radykalny w sprawach wiary od swojego poprzednika. W wielu wsiach za sprawą hodżów kształconych w Arabii Saudyjskiej zmienia się charakter religijności, coraz bardziej zatracając swój ludowy rys.

20 Por.: В. Кръстанова, М. Петрова, Ел. Николова, М. Михайлов, Н. Томова, Честотен речник на личните имена в Смолянско, Смолян 2010. 
wało im się najbliższe temu, jaki dotąd nosili. W praktyce o doborze nowego antroponimu decydowała możliwość doboru względnie bliskiego znaczenia (por. Ziumbiul ${ }^{1}$ - Cwetelina) najczęściej jednak wytyczną była tożsama pierwsza litera imienia, m.in. dlatego tak rozpowszechnione wśród pomackich kobiet jest imię Albena, którym zastępowano niezwykle popularne wśród muzułmanek imię Aiszé i inne zaczynające się od litery A .

Przynależność do społeczności muzułmańskiej wydaje się być dla mieszkańców wsi tematem tabu (w związku z tym spotkałam się nawet z twierdzeniem, że Selczę zamieszkują kryptochrześcijanie ${ }^{22}$ ), jak wspomniano wyżej, niechętnie używają oni przy obcych swoich prawdziwych imion i nazwisk, posługując się na co dzień ich bułgarskimi odpowiednikami, nadanymi przez komunistyczne władze w latach 70. i 80. XX wieku. Jedna z mieszkanek Selczy, jak gdyby wstydząc się, czy też odczuwając zażenowanie z powodu wyznawanej religii, przytoczyła mi w $2008 \mathrm{r}$. ciekawą legendę na temat okoliczności przejścia miejscowej ludności na islam:

Kiedyś dawno, w naszej wsi mieszkali sami Bułgarzy chrześcijanie. Nawet do dzisiaj jedną taką część, no taki kwartał malutki - o tam, w tej starej części wioski - nazywamy czerkwa, że cerkiew niby, tylko tak po naszemu, po rodopsku. Tam cerkwi nie ma, nie ma nawet po niej śladu, ale kto wie, może kiedyś była? No, na pewno była, bo inaczej by tak ludzie tych paru domów nie nazywali, prawda? [...] Jak przyszły tureckie czasy zrobiło się gorzej, bo ciagle wojska jakieś tędy ciągnęły, potem nawet koszary założyli. [...] No, ale najgorsze co się może stać, to jak przyroda jest przeciwko człowiekowi. I tak się zdarzyło, że przez kilka lat ziemia plonu nie dawała jak trzeba, że nawet trawy dla owiec i siana zaczęło brakować i nastał straszny głód. I ten głód był tak wielki, że ludzie zaczęli umierać, miazgę z drzew jedli, podobno nawet mieloną korę z sosen zamiast mąki, ale i tak nie starczyło dla wszystkich i potem już zupełnie nie było co jeść. Modlili się, ale Bóg jedzenia nie zsyłał, nie posypała się manna z nieba. Umarliby pewnie wszyscy gdyby nie przypadek. Pewnego dnia pojawił się na polowaniu w naszych okolicach sam sułtan. Nie wiem na co polował, może na niedźwiedzie, bo tam wysoko w górach, to jeszcze do dzisiaj niedźwiedzie żyją. Może polował na sarny, albo dziki, tego nie wiem. Wiem, że polował i że patrzył z góry na okolicę, i zobaczył, że wioski głodują. Zapytał wtedy miejscowego agę, zarządcę takiego: „Kim są ci głodni ludzie w wioskach?”. Aga powiedział „To twoi poddani sułtanie, ale nie żałuj ich, bo trzymają się swojej wiary”. Ale sułtan był mądry i kazał adze zejść do wsi i powiedzieć, że da ludziom wiele worków zboża, tak dużo, że już nie będą głodować, pod warunkiem, że przejdą na wiarę w Allacha. Ludzie usiedli, myśleli, naradzali się, ale śmierć to rzecz straszna, nikt nie chce umierać, a z głodu tym bardziej. No więc przyjęli propozycję sułtana i sami z własnej woli wiarę muzułmańską przyjęli. ${ }^{23}$

Ta sama kobieta przedstawiała siebie i swoje rówieśniczki jako inicjatorki nowego sposobu ubierania się, który spowodował rezygnację z tradycyjnych czarnych okryć, zwanych feredże (tutaj należałoby zaznaczyć, ze kobiety z Selczy nigdy nie ubierały się w szarawary i inne tradycyjne okrycia noszone jeszcze dziś np. w niektórych wsiach w okolicach Goce Delczew):

21 Tur. 'hiacynt'.

22 Taki pogląd dotyczący Pomaków propagowali m.in. Straszimir Sziszkow i Krasimir Stoiłow.

23 M. Mikołajczak, Powiedz mi..., op. cit. s. 24. 
[...] my tutaj we wsi dawno już przestałyśmy nosić feredże. [...]”. Jak ślub braliśmy, to miałam tak jak wszystkie panny młode białą suknię, a na tym czarne manto. [...] No więc tak, jak wszędzie na wsi, tak i tutaj można było poznać która panna, a która mężatka, bo panny inaczej wiązały chustkę, a inaczej zamężne. [...] chustka nie jest najważniejsza. Ważniejsze jest manto. Chyba. Tak mi się wydaje, bo przez jakiś czas zakazali nam je nosić. To było dawno temu, bardzo młoda byłam, ale pamiętam, że przyjechał ktoś do wsi, jakiś sekretarz z partii czy ktoś taki i kazał nam ubierać się inaczej i czymś tam straszył niepokornych i w ogóle...[...] W każdym razie nosiłam je tylko jakiś rok po ślubie. Potem już nie było wolno. No więc założyłam fartuch, tak jak wszystkie kobiety we wsi, ale jakoś źle się z tym czułam, wydawało mi się, że chodzę po wsi rozebrana, że robię coś nie tak jak trzeba. [...] Ten roboczy fartuch z ciemnoniebieskiego płótna był prawie taki sam jak manto, ale nie czułam się w nim dobrze. Męczyłam się w nim i ani w pracy, ani w domu nie było mi dobrze. Aż miałam sen...

[...] W każdym razie w tym moim śnie poszłam tamtą drogą dalej, minęłam meczet i doszłam do cmentarza. Skręcam w prawo, idę spokojnie, aż tu nagle jakiś głos nie wiadomo skąd mówi do mnie i słyszę go wyraźnie: „Kitko, źle ci w tym bułgarskim fartuchu, chciałabyś nasze pomackie manto, prawda?". Pyta mnie więc ten głos, a ja nie wiem komu odpowiadać! Ale głos dalej ciagnie. Kitko, mówi, ,teraz nowe czasy, teraz nie możesz chodzić po wsi tak, jak za Turka, teraz Bułgaria tu jest i innych ubrań wymaga, zmień się i ty". Tak mi ten głos we śnie mówił, a ja mu wierzyłam, więc zebrałam się na odwagę i zapytałam „w co mam się ubierać?’. A głos mi mówi: „Oszukaj ich trochę. Uszyj to samo, ale nie takie samo. Uszyj sobie manto, ale z materiału w kwiatki. Allach chce żebyś tak zrobiła. Bułgarzy będą zadowoleni, ty będziesz miała czyste sumienie... Zrób tak”. I wierz mi, posłuchałam tego głosu. Sen nie sen, sprawdzić warto. I robię tak od ponad czterdziestu lat i dobrze mi z tym. Inne kobiety we wsi też zaczęły tak samo jak ja szyć sobie manto z materiału we wzory jakieś, najczęściej w kwiaty i też są zadowolone ${ }^{24}$.

Moje rozmowy z mieszkańcami Selczy miały miejsce głównie podczas tzw. syborów” (bułg. събор 'zjazd, zebranie') tj. rodzinnych zjazdów wszystkich osób pochodzących z tej wsi, a jednocześnie wiejskich festynów, odbywających się od początku lat dziewięćdziesiątych corocznie w pierwszą sobotę i niedzielę sierpnia. Pobliskie rozległe łąki gromadzą wówczas niemal całą, rozproszoną po całym kraju, społeczność wywodząca się z tej niewielkiej rodopskiej miejscowości. Do Selczy zjeżdżają nie tylko ci, którzy się tutaj urodzili, a potem wyjechali w poszukiwaniu pracy, ale także ich potomkowie. Przez kilka sierpniowych dni wieś gromadzi znowu ok. 2 tys. osób. W mojej opinii jednak właśnie te zjazdy przyczyniają się do błyskawicznej zmiany miejscowych obyczajów, np. akceptacji coraz bardziej ,zachodniego” sposobu ubierania się młodych kobiet, szczególnie tych, które mieszkają w miastach (przy jednoczesnym zachowaniu tradycji przez starsze pokolenie), czy rezygnacji z tańców przy autentycznej ludowej muzyce na rzecz obecnej od lat w bułgarskiej kulturze popularnej tzw. czałgi, będącej swoistym połączeniem elementów folklorystycznych z muzyką turecką i grecką, zespolonych jednoczesnym nadaniem tekstom piosenek zabarwienia erotycznego. Utwory te, tańczone wciąż w sposób tradycyjny (tzw. choro) zdają się już od kilku lat nie razić uszu starszych mieszkańców wioski, oglądających najchętniej kanały telewizyjne emitujące taką właśnie „orientalną” muzykę lub tureckie opery mydlane.

${ }^{24}$ M. Mikołajczak, Powiedz mi..., op. cit. s 81-84. 
Akceptację zyskały także małżeństwa mieszane, do niedawna zdarzające się sporadycznie, chociaż podobno jeszcze na początku XX wieku mieszkało w Selczy kilka rodzin chrześcijańskich (dowodem na długotrwałe utrzymywanie się chrześcijaństwa na tych ziemiach są lokalne mikrotoponimy: Чарква, Давидово, Марина, Попин Дол, Николов гроб itp). Mieszkańcy wsi od kilku lat chętnie manifestują swoją odrębność i nieprzystawalność do tych okolicznych wsi, które uznają za „tureckie” (za obcą wieś uznają m.in. położone najbliżej, bo zaledwie 6 kilometrów dalej - czy może raczej niżej - Stomanowo) lub mieszane. Różnice między poszczególnymi wsiami uwidoczniają się najwyraźniej podczas kolejnych wyborów do parlamentu czy samorządów, w których „Turcy” głosują na partie tureckie, Bułgarzy dokonują różnorakich wyborów, a Pomacy wierni są partii BPS, czyli socjaldemokracji, kontynuującej działania dawnej partii komunistycznej, która, chociaż pozbawiła ich tożsamości, nakazując zmienić imiona i nazwiska, to jednak zapewniała pracę i utrzymanie. Zatem sentyment do czasów, gdy całe rody mogły żyć wspólnie (o czym dziś świadczą już tylko ziejące pustką okazałe dwupiętrowe domy) i utrzymać się z tradycyjnych zajęć, bez konieczności opuszczania wsi, każe im wciąż wrzucać do urn wyborczych karty w kolorze pomarańczowym.

\author{
POMAKS-TURKIFIED POMAKS \\ (ON THE EXAMPLE OF SELCHA VILLAGE \\ IN THE WESTERN PART OF THE RHODOPE MOUNTAINS)
}

\author{
MARIOLA WALCZAK-MiKOŁAJCZAKOWA
}

Summary

The Selcha village, situated at the Smolian District, inhabited by Pomaks, a specific ethnos, created itself after acceptance of Islam, most likely at the turn of XVI and XVII century. Currently, this large village once (about 2 thousands inhabitants in the mid-twentieth century) shares the fate of others, "ageing" and 'moribund' village communities in Bulgaria. Author tries to recreate a complicated history of this village, in orde to analyse the reasons of gradual atheisation. The author discusses the problem of the simultaneous attachment to some traditions and giving up on other traditions on the basis of the stories of inhabitants stories, , legends stored in their memories and well-retained documents. All of this become a pretext to discuss (from the sociological perspective) a change of the type of husbandry and the political decisions made during the parliament elections. 